\title{
A voz do sujeito marginal nas obras Acidente de trabalho, de Eugênio Sigaud e Construção, de Chico Buarque ${ }^{1}$
}

\author{
Liliane Barros O. Delorenzi²
}

O texto original desse artigo foi substituído por essa versão corrigida em outubro de 2014, devidamente atualizado pela autora, atendendo a um pedido do professor José De Nicola Neto, já que ideias e passagens da obra de sua autoria Literatura Brasileira - das origens aos nossos dias foram utilizadas de forma indevida no texto original. Os editores solicitaram a inclusão das referências, publicando a versão completa do texto e assegurando os direitos autorais dos trechos citados, lembrando que, conforme as normas de publicação na revista, a responsabilidade pelo conteúdo dos artigos é de inteira responsabilidade de seus autores, inclusive cabendo a eles a apresentação de permissão para uso de imagens, ilustrações, tabelas, gráficos de terceiros que, porventura, venham a integrá-lo. 


\section{Resumo}

A partir da relação entre o verbal e o pictórico, o trabalho apresenta conceitos bakhtinianos sobre o signo como arena onde se desenvolve a luta de classes. Utilizou-se como corpus a música de Chico Buarque, Construção, e a pintura de Eugênio de Proença Sigaud, Acidente de trabalho. Nesse contexto, é possível observar como as personagens se constroem em ambas as artes, como as vozes centrífugas e as posições ideológicas dos sujeitos se assumem perante uma sociedade opressora e mecanicista. Para tanto, relacionamos as obras a fatores externos de ordem social, histórico e cultural. A fundamentação teórica do trabalho foi baseada no pensamento de Mikhail Bakhtin e outros autores que retomam em seus trabalhos os princípios desse autor.

\section{Palavras-chaves}

Sujeito, força centrífuga, trabalho, sociedade, luta de classes.

\section{Abstract}

This work presents some bakhtinian's concepts on the sign understood as the arena where the class struggle takes place. The corpus used was the music "Construção", by Chico Buarque and the painting, Acidente de trabalho, by Eugênio de Proença Sigaud. In both, it can be seen the conception of characters' image, how their centrifugal voices and ideological positions are presented in a mechanistic and oppressive society. Therefore, we relate the arts with social, historical and cultural external factors. The theoretical approach was based upon Mikhail Bakhtin thoughts and others authors that incorporate his ideas in their works.

\section{Keywords}

Character, centrifugal strength, work, society, classes fighting. 
A origem dialógica da linguagem é um conceito fundamental nas obras de Mikhail Bakhtin. Seu pensamento principal volta-se para a construção do discurso que se elabora a partir do outro. Ou seja, a forma como o discurso do eu está perpassado, atravessado e condicionado pelo discurso do outro.

\begin{abstract}
A orientação dialógica é naturalmente um fenômeno próprio a todo discurso. Trata-se da orientação natural de qualquer discurso vivo. Em todos os seus caminhos até o objeto, em todas as direções, o discurso se encontra com o discurso de outrem e não pode deixar de participar, com ele, de uma interação viva e tensa (BAKHTIN, 1988, p.88).
\end{abstract}

As reflexões de Bakhtin acerca da linguagem humana como promotora da interação social e expressão ideológica têm influências em inúmeros estudos nas últimas décadas. Ao tratar do papel da consciência individual e da palavra nas formações das ideologias, Bakthin apresenta uma série de reflexões no sentido de facilitar nossa compreensão sobre a importância dos processos de interação dos grupos sociais.

Essa cadeia ideológica estende-se de consciência individual em consciência individual, ligando umas às outras. Os signos só emergem, decididamente, do processo de interação entre uma consciência individual a uma outra. E a própria consciência individual está repleta de signos. A consciência só se torna consciência quando se impregna de conteúdo ideológico (semiótico) e, conseqüentemente, somente no processo de interação social (BAKHTIN, 1990, p.34).

Para o autor, a palavra, além de constituir o mais puro signo ideológico na manutenção das relações sociais, ainda serve de suporte para todo signo não verbal, sendo eles também entendidos como signos ideológicos.

Temos, pois, que todo signo - verbal ou não - só existe enquanto tal, devido à carga ideológica que comporta, de forma a tornar possível a formação das subjetividades e os processos de interação humanas.

A palavra acompanha e comenta todo ato ideológico. Os processos de compreensão de todos os fenômenos ideológicos (um quadro, uma peça musical, um ritual ou um comportamento humano) não podem operar sem a participação do discurso anterior. Todas as manifestações 
da criação ideológica - todos os signos não-verbais - banham-se no discurso e não podem ser nem totalmente isoladas nem totalmente separadas dele (BAKHTIN, 1990, p.37-38).

Dessa forma, ao se tomar o diálogo entre os interactantes como um palco de batalhas ideológicas, visões de mundo e conhecimentos entram em constante conflito visando engajar discursivamente os participantes em um processo de reflexão sobre a própria ação. Por isso, consideramos fundamental compreender o discurso como o meio através do qual seja possível entender que a nossa participação nas mais diversas esferas da vida social determina quem somos, como avaliamos o outro e como pensamos que esse outro nos avalia, desencadeando um processo ininterrupto de (re)construção de identidades.

A proposta deste estudo, portanto, é a partir da relação entre o verbal e o pictórico, apresentar conceitos bakhtinianos sobre o signo como arena onde se desenvolve a luta de classes, aplicando-os a uma análise de algumas relações dialógicas estabelecidas entre a obra de Chico Buarque Construção, e a pintura de Eugênio de Proença Sigaud Acidente de trabalho (fig.1). Nesse contexto, veremos também como o sujeito se constrói em ambas as obras, que vozes se mostram e que posições ideológicas assumem perante uma sociedade opressora e mecanicista.

Para fundamentação teórica do trabalho baseamo-nos nas obras Marxismo e filosofia da linguagem, de Bakhtin e Voloshinov, e Questões de literatura e estética, de Bakhtin. Entretanto, o texto foi entrecortado por autores como Carlos Faraco (2003) e Linda Hutcheon (1985), que retomam em seus trabalhos os princípios de Mikhail Bakhtin e outras obras do próprio autor. Para interpretação e análise das obras selecionadas, baseamo-nos nas colocações de José Nicola, em sua obra Literatura brasileira - da origem aos nossos dias (2003).

A escolha do corpus se dá em virtude de ambos os textos dialogarem demonstrando a situação do trabalhador da construção civil, excluído e explorado, levando o leitor a refletir sobre a necessidade de mudança nas condições de trabalho dos operários que representam aquele momento histórico. Assim, 
perceberemos que, como afirma Bakhtin, um texto é voz que dialoga com outros textos, mas também funciona como eco de seu tempo, da história de um grupo social, de seus valores, crenças, preconceitos, medos e esperanças.

\section{Contexto histórico-social}

O Brasil experimentou a partir século passado um rápido crescimento da construção civil. Após ser promulgada a Lei no 2332, em 1920, que regulamentava a altura dos edifícios e o uso de elevadores, a cidade de São Paulo dá o primeiro passo para a construção de inúmeros prédios com altura muito superior a três ou quatro andares, tamanho padrão até aquela época. Tem início, então, o processo de verticalização do país e a demanda de operários para atenderem a esse rápido crescimento da engenharia civil. Em meio a essa realidade, o trabalhador se torna uma máquina que realiza sua função sem pensar ou questionar. Os passos devem ser seguidos metodicamente para que não se perca tempo nem dinheiro. Esse meio capitalista acaba por reduzir o indivíduo à condição de objetos, provocando estratificação social e um maior número de conflitos na sociedade humana, gerando vozes e consciências que resistem a tal redução.

Assim, os sujeitos excluídos ganham voz nas obras de Sigaud e Buarque: por meio de um processo de identificação, o discurso pode causar, nos cidadãos "reais", um sentimento de inquietação. A canção e a tela, enquanto gêneros artísticos, têm o poder de despertar nos cidadãos, a consciência crítica e a sentimento de revolta. Entendemos que o sujeito da canção passa a ser o outro, com quem os sujeitos excluídos brasileiros podem se identificar e re-pensar sua condição social. Como observamos em Questões de literatura e estética:

(...) porque de dentro de mim mesmo existe apenas a minha autoafirmação interna, que eu não posso projetar sobre minha expressividade externa separada da minha auto-sensação interna, porque ela se contrapõe a mim no vazio axiológico, na impossibilidade de afirmação (BAKHTIN, 1988, p.29). 
Sob esse olhar, entendemos a força do discurso para afastar os sujeitos do poder e dar voz àqueles que são excluídos. Por meio do discurso, a ordem social pode ser mantida ou "destruída". Percebemos que o discurso não se resume a uma série de enunciados que representam uma expressão verbal, mas que ele se constitui como uma prática de poder que representa uma ideologia. Em meio a essa luta de vozes que Bakhtin conceitua a palavra, como:

(...) a arena onde se confrontam os valores sociais contraditórios; os conflitos da língua refletem os conflitos de classe no interior mesmo do sistema: comunidade semiótica e classe social não se recobrem. A comunicação verbal, inseparável das outras formas de comunicação, implica conflitos, relações de dominação e de resistência, adaptação ou resistência à hierarquia, utilização da língua pela classe dominante para reforçar seu poder etc (BAKHTIN, 1990: 14).

É com foco nas vozes centrípetas, que lutam contra uma ideologia dominante e que fazem do signo "uma arena onde se desenvolve a luta de classes", que passamos à análise das obras selecionadas.

\section{A denúncia social no signo não verbal}

(...) uma imagem é, com efeito, de início, por si mesma, presença. Ela nos põe imediatamente em contato com alguma coisa que não é um discurso sobre algum referente suposto (...), mas que é, nem mais nem menos, a presença da própria imagem enquanto tal, como realidade plástica (LANDOWSKI, 1998, apud ALVAREZ, 2006, p.67).

Considerando algumas categorias plásticas, observaremos como a pintura de Sigaud, de 1944, Acidente de trabalho, se constrói como voz daqueles que estão marginalizados pelo poder.

Nicola (2003, p.4) destaca a cena que é retratada na tela, um cenário formado por vários edifícios em construção, características claras de um espaço urbano. Além disso, o autor chama atenção para o ângulo sob o qual enxergamos essa cena, "de cima para baixo, como se estivéssemos em um dos andaimes, ao lado dos trabalhadores que aparecem em primeiro plano". Esse ângulo da cena 
nos remete à idéia de que, muito provavelmente, foi de um desses andaimes que caiu o trabalhador, que aparece estirado no chão. Ou seja, somos levados, através de uma aproximação, para a posição original do operário antes da queda.

Se traçarmos um corte vertical na tela temos, ao centro, a figura do operário caído. A luz e a posição o colocam no foco principal, ou seja, o ponto para onde se voltam todas as atenções. Além disso,

(...) os prédios em construção produzem zonas de luz e zonas de sombra, o corpo do operário está estendido exatamente na principal zona de luz, como se ele estivesse sob o foco de um holofote, impossível, portanto, não tomar conhecimento da tragédia (NICOLA, 2003, p.4).

Entretanto, o que vemos na reação das pessoas que o rodeiam é um afastamento, ou mesmo uma ignorância do fato ocorrido, como se este fosse um evento sem importância ou corriqueiro.

Ainda observando os traços na tela, vemos uma série de linhas verticais que nos remetem ao momento histórico que a construção civil vivia naquele momento. Como foi dito, desde a década de XX o Brasil experimentava um processo de verticalização com a construção de grandes prédios.

Nessa década, para Abe ocorreram,

(...) profundas transformações, verificando-se um intenso processo de verticalização com a edificação em seu interior de prédios de apartamentos e, em suas avenidas, a construção de edifícios de escritórios e centros comerciais (ABE, 1999, p.377).

Como muito bem aponta Nicola (2003), um ponto dialógico pode ser notado no canto superior esquerdo da tela, onde percebemos alguns pássaros voando, cena que será citada no texto de Chico Buarque, quando, por um instante o operário da construção é comparado ao pássaro flutuando no espaço. "E flutuou no ar como se fosse pássaro".

Observamos, também, que os corpos dos trabalhadores que aparecem no canto superior direito da tela são desproporcionais se compararmos seus 
membros às cabeças. "(...) essa desproporcionalidade acentua o fato de serem trabalhadores braçais, que desenvolvem mais a força física do que o intelecto" (NICOLA, 2003, p.4). Nesse ponto, podemos relacionar as idéias de Focault (2003) que, sob a ótica do pensamento marxista, aponta para uma análise que relaciona saber e poder na sociedade contemporânea e propõe a luta de classes como propulsora da movimentação histórica. As posições ocupadas pelo sujeito dentro da sociedade capitalista, ou seja, dentro de uma hierarquia o poder, determinam as diferenças de classes imposta por ela. Como destaca J. Kowaga, cabe, nesse ponto, distinguir a concepção de poder elaborada por Focault, que se contrapõe com a corrente althusseriana.

(...) que entende o poder como algo que se direciona à classe dominante - dos aparelhos ideológicos e repressivos de Estado - para a classe dominada. Foucault, por sua vez, propõe que se entenda o poder como micro-poder (KOWAGA, 2007, p.4).

Nesse sentido, o poder é entendido como uma estratégia, como algo que se exerce mais do que se possui. Kowaga (2007) explica que o poder se estende por todas as camadas da sociedade e embrenha-se pelas mais ínfimas relações sociais. É isso que entendemos como poder em escala micro, como destacado em Vigiar e punir:

\footnotetext{
Ora, o estudo desta microfísica supõe que o poder nela exercido não seja concebido como uma propriedade, mas como uma estratégia, que seus efeitos de dominação não sejam atribuídos a uma "apropriação", mas a disposições, a manobras, a táticas, a técnicas, a funcionamentos; (...) O que significa que essas relações aprofundam-se dentro da sociedade, que não se localizam nas relações do Estado com os cidadãos ou na fronteira das classes e que não se contentam em reproduzir ao nível dos indivíduos, dos corpos, dos gestos e comportamentos, a forma geral da lei ou do governo (FOUCAULT, 2003, p.26).
}

Foucault estabelece uma relação importante entre saber e poder. $\mathrm{Na}$ divisão de poder, as posições sociais mais privilegiadas são aquelas que exigem dos sujeitos, um maior grau de especialização do saber. Portanto, ficam excluídos dessas posições "superiores" os sujeitos que não possuem um grau de saber legitimamente reconhecido sócio-institucionalmente (KOGAWA, 2007). 
Ainda atentando para a maneira como Sigaud constrói os personagens de sua obra, uma boa parte do grupo de operários transita no escuro da tela. Além disso, observamos que os operários não possuem rosto ou eles não se mostram claros na pintura. Essa é mais uma forma de mostrar como se configura esses sujeitos marginalizados, pessoas sem nome, sem voz, sem identidade.

A tela Acidente de trabalho é mais um enunciado visual que reflete a classe operária que vivia na metade do século passado e a temática de "tipos regionais do Brasil". Assim como outros pintores modernistas, como Tarsila do Amaral e Cândido Portinari, Sigaud vê a arte como forma de denúncia social tanto nos centros urbanos como no meio rural. Nesse sentido, podemos destacar a obra Operários (fig. 2), de Tarsila do Amaral, onde a artista produz uma tela de análise social. Rostos tristes de diversas etnias se espremem diante das chaminés das fábricas na cidade de São Paulo, metáfora da industrialização e da demanda de emprego que não cresce na mesma proporção. Assim como em Lavrador de Café (fig. 3), de Portinari, umas das mais famosas do pintor que retratou a força, o movimento e o desafio do trabalhador, nesta pintura observamos como "o corpo parece estar unido para sempre à terra vermelha, viva, os enormes pés fincados e firmes sugerindo a busca e a conquista da terra" (ROSA, 1999, p.15). Uma boa parte da obra de Sigaud voltou-se para retratar o trabalho e o trabalhador, ficando conhecido como "o pintor de operários".

\section{Relações dialógicas}

Cada enunciado é pleno de ecos e ressonâncias de outros enunciados com os quais está ligado pela identidade da esfera da comunicação discursiva. Cada enunciado deve ser visto antes de tudo com uma resposta aos enunciados precedentes de um determinado campo (...): ele os rejeita, confirma, completa, baseia-se neles, subtende-os como conhecidos, de certo modo os leva em conta (BAKHTIN, 2003, p.297, grifo do autor).

A música tem participado, com as outras artes, neste "virar-se para dentro" geral, a fim de reflectir sobre a própria constituição (HUTCHEON, 1985, p.13). 
No texto de Chico Buarque, observamos uma clara homenagem à obra de Sigaud.

Por meio de uma paródia sacralizadora, Buarque retoma o tema da vida do trabalhador da construção civil, conferindo voz a esse sujeito marginal. As imagens de Sigaud ganham vida ao dialogar com a crítica buarqueana a um poder opressor das classes baixas. Portanto, através dessa troca constitui-se o enunciado que não existe fora das relações dialógicas, como afirma L. Fiorin:

Nele [no enunciado] estão sempre presentes ecos e lembranças de outros enunciados, com que ele conta, que ele refuta, confirma, completa, pressupõe e assim por diante. Um enunciado ocupa sempre uma posição numa esfera de comunicação sobre um dado problema (FIORIN, 2008, p.21).

Construção foi composta por Chico Buarque em 1971, em pleno regime ditatorial brasileiro e num momento em que o Brasil passava por um novo processo de expansão industrial.

No texto de Chico Buarque, temos uma narração em terceira pessoa. 0 narrador não participa dos acontecimentos; os operários são o outro, isto é, as pessoas de quem se fala; há um evidente distanciamento dos fatos, ao contrário do que ocorre com a tela de Sigaud (NICOLA, 2003, p.4).

Para Bakhtin, o sujeito deve ser entendido como um eu, que se constitui a partir e por meio de um outro. Ao propor uma filosofia marxista da linguagem, Bakhtin afirma que somente no âmbito da interação verbal - portanto, relação eu-outro - é que podemos obter uma filosofia materialista da linguagem. O diálogo se configura, portanto, como a maneira mais concreta de manifestação discursiva (KOGAWA, 2007).

Ao ler o texto de Chico Buarque, percebemos uma forte marcação de ritmo. Nicola $(2003$, p.4) ressalta que as palavras proparoxítonas que encerram cada verso "são responsáveis por um ritmo que se arrasta produzindo um efeito muito sugestivo de alguma coisa que se prolonga; no caso, há uma íntima relação entre esse ritmo e a vida do operário que se arrasta cotidianamente". Esse efeito, ainda segundo o autor, 
é reforçado pela repetição parcial dos versos, em que a alteração ocorre somente com as palavras proparoxítonas. Assim, os próprios versos funcionam como refrão, marcando o clímax do texto ("Morreu na contramão atrapalhando...").

Os versos "Amou daquela vez como se fosse a última / Beijou sua mulher como se fosse a última / E cada filho seu como se fosse o único / E atravessou a rua com seu passo tímido" comprovam que o sujeito da canção é um personagem masculino, casado, pai de família. Existe um convívio amoroso com sua mulher ("beijou [...] como se fosse a última") e um indicativo de que possui mais de um filho ("e cada filho seu"). Há um apontamento para uma possível "realidade" brasileira daquela época e da atual: a do trabalhador com mulher e muitos filhos para cuidar. O autor mostra que esse sujeito, mais que um trabalhador, é membro de uma família onde estabelece laços afetivos. Ou seja, sua relação com o mundo não está só atrelada ao meio profissional, existem outros sujeitos retratados também por essa figura. Outra ideia sugerida é a de que ele seja um homem de baixa condição social, devido ao andar tímido, que transparece a submissão aos demais na rua (SENKEVICS, 2007).

O tema da canção, bem como a profissão do homem, ficam evidenciados pelos versos "Ergueu no patamar quatro paredes sólidas / Tijolo com tijolo num desenho mágico" e "Subiu a construção como se fosse máquina". Senkevics (2007) ressalta que a rotina de trabalho é comparada a de uma máquina. Isto sugere que o homem trabalha sem pensar ou questionar o que faz, apenas está condicionado ao seu trabalho, algo tão comum que o faz automaticamente. Os passos de suas tarefas devem ser seguidos metodicamente para que não se perca tempo nem dinheiro. Essa é uma das marcas da sociedade capitalista contemporânea e da força opressora do poder que Bakhtin aponta sua oposição em Problemas da poética de Dostoievski:

Aqui é oportuno assinalar que a ênfase principal, de toda obra de Dostoievski, quer no aspecto da forma, quer no aspecto do conteúdo, é uma luta contra a coisificação do homem, das relações humanas e de todos os valores humanos no capitalismo (BAKHTIN, 1981, p.53). 
Uma das partes mais sentimentais da música está na interpretação dos versos "Seus olhos embotados de cimento e lágrima", pois mistura um objeto frio e nem um pouco emotivo, o cimento, com um símbolo do sentimentalismo e da sensibilidade, a lágrima. Para Senkevics (2007), o fato importante desse paradoxo é ver que podem coexistir, nos olhos do trabalhador, a frieza do cimento com a fraqueza das lágrimas, algo que em muito reflete o sofrimento desta condição social: a rigidez imposta com o sentimento oprimido.

Nas passagens "Sentou pra descansar como se fosse sábado / Comeu feijão com arroz como se fosse um príncipe", fica evidenciado o alívio da hora do descanso. Sábado é o primeiro dia do fim de semana, aquele dia que vem logo após a semana atribulada. Quando o intervalo do serviço é comparado a sábado, a necessidade de descanso é realçada. O ato de almoçar uma comida tão simples e comum, como o feijão e arroz, e se sentir um príncipe, indica um gosto muito grande por uma combinação cotidiana, como se não se pudesse escapar desta rotina (SENKEVICS, 2007). Em vários momentos como este, o sujeito parece pressentir estar vivendo seus últimos momentos de vida e tenta aproveitá-los de maneira máxima.

Os versos "Bebeu e soluçou como se fosse um náufrago / Dançou e gargalhou como se ouvisse música", evidenciam o alcoolismo e a alegria momentânea proporcionada pela bebida, que resulta no acidente fatal: "E tropeçou no céu como se fosse um bêbado / E flutuou no ar como se fosse um pássaro / E se acabou no chão feito um pacote flácido".

Os últimos momentos de vida daquele homem são mostrados nos versos "Agonizou no meio do passeio público/ Morreu na contramão atrapalhando o tráfego". Fica evidente, na última frase, a indiferença quanto à morte daquele cidadão ao cair do prédio e estatelar-se no chão. A única preocupação que ocorre por parte do público que ali estava foi em relação ao trânsito, como se qualquer objeto tivesse caído, e não um pai de família. Senkevics (2007) chama atenção para a contradição existente nessa cena, dentro de casa, o homem era o chefe, o pai, o líder, mas na rua é um sujeito qualquer, mais uma peça da 
engrenagem capitalista. Essa indiferença fica ainda mais evidente nos versos "Morreu na contramão atrapalhando o público" e, ainda, em "Morreu na contramão atrapalhando o sábado". O sábado é o principal dia de descanso do trabalhador. A morte no sábado causa ainda mais transtornos para o público, que poderia estar passeando por ali no seu dia de descanso. Somente nesse momento, o homem que nem nome tem, tão coisa que é, é notado pelas outras pessoas. Enquanto ele erguia paredes, o público passeava. Na hora em que se acidentou e morreu, passou a ser notado pelo incômodo que causou. Ao observarmos a morte do sujeito e a indiferença com que o sistema trata esse fato, notamos que o agir do sujeito não é valorizado como tal, mas como a ação de um objeto.

\footnotetext{
As estrofes começam com "amou" e terminam com "morreu", outra antítese muito interessante da letra que destaca a narrativa, onde as coisas começam bem e, de uma maneira ou de outra, terminam num fim. Neste caso, o fim é sua própria morte, deixando para trás o seu lar, onde sua posição como líder era muito importante; deixa de lado também seu trabalho, onde era insignificante (SENKEVICS, 2007, p.4).
}

A canção de Buarque dialoga não só com a linguagem visual de Sigaud, mas, obviamente, como o momento histórico da sociedade brasileira no momento de produção da canção que foi marcado por acidentes de trabalho, baixos salários e longas jornadas de serviço. O crescimento das indústrias e o incentivo dado às multinacionais traziam benefícios "reais" apenas às classes média e alta. A classe trabalhadora era explorada e submetida a longas jornadas de trabalho devido aos baixos salários. Trabalhava-se mais para compensar a baixa salarial. Além disso, o número de acidentes de trabalho era muito elevado. Essa é outra marca contextual que nos permite realizar uma leitura crítica de Construção. O sujeito da canção cai do andaime, fator que o leva à morte. Na época, o Brasil foi considerado campeão mundial em acidentes de trabalho. (BRAGA, online) A canção tem o poder de despertar nos cidadãos a consciência crítica e a sensação de revolta. Por isso, confirmamos os vínculos que se estabelecem entre a obra e a ideologia do cotidiano, ou seja, a realidade em que os personagens dos textos literários estão inseridos. 


\begin{abstract}
A obra é interceptada no espírito desse conteúdo da consciência (dos indivíduos receptores) e recebe dela uma nova luz. É nisso que reside a vida da obra ideológica. Em cada época de sua existência histórica, a obra é levada a estabelecer contatos estreitos com a ideologia cambiante do cotidiano, a impregnar-se dela, a alimenta-se da seiva nova secretada. É apenas na medida em que a obra é capaz de estabelecer um tal vinculo orgânico e ininterrupto com a ideologia do cotidiano de uma determinada época, que ela é capaz de viver nesta época (BAKHTIN; VOLOSHINOV,1990, p.121).
\end{abstract}

\title{
Considerações finais
}

Há, nos discursos de Sigaud e Buarque, ênfase nos percursos temáticos da modernização, a crítica ao capitalismo e o despertar da consciência social para uma realidade que marginaliza uma maioria e dá poder absoluto a uma minoria.

A canção de Chico Buarque recupera, décadas depois, o tema do trabalhador "mecanizado". Por resgatarem uma mesma formação discursiva, as obras mantêm uma relação contratual com objetivos comuns e se "apóiam" uma na outra para dar maior credibilidade ao que está sendo observado.

\footnotetext{
O enunciado é pleno de tonalidades dialógicas, e sem levá-las em conta é impossível entender até o fim o estilo de um enunciado. Porque a nossa própria idéia - seja filosófica, científica, artística - nasce e se forma no processo de interação e luta com os pensamentos dos outros, e isso não pode deixar de encontrar o seu reflexo também nas formas de expressão verbalizada do nosso pensamento (BAKHTIN, 2003, p.298).
}

Os artistas percebem sua obra como um instrumento de denúncia, de crítica, de representação de uma realidade desumana e injusta. A obra de um artista é o veículo para a denúncia daqueles que se encontram à margem da sociedade, para aqueles que são vistos apenas como "máquinas" e "pacotes" a serviço dos opressores. O homem deve deixar de ser marcado pela inutilidade para ser visto como ser significante, de forma que tenha voz para exercer sua liberdade e o seu direito a uma vida digna. O homem deve lutar contra a força centrípeta que o prende e o marginaliza. Sigaud e Buarque apontam para uma estrutura social que não gostariam que existisse, para uma coisificação do homem 
que não deve persistir. Eles apontam para mundo "polifônico", não apenas como um universo de muitas vozes, mas um lugar onde todas as vozes são eqüipolentes, plenivalentes. Sendo essa polifonia uma única forma de preservar a liberdade do ser humano, o "mundo polifônico é onde a multiplicidade de vozes plenivalentes e de consciências independentes e não fundíveis tem direito à cidadania - vozes e consciências que circulam e interagem num diálogo infinito - o simpósio universal" (FARACO, 2003, p.74). Assim, como aponta Bakhtin em relação à obra de Dostoievski:

A multiplicidade de vozes e consciências independentes e imiscíveis e a autêntica polifonia de vozes plenivalentes constituem, de fato, a peculiaridade fundamental dos romances de Dostoiévski. Não é a multiplicidade de caracteres e destinos que, em um mundo objetivo e uno, à luz da consciência una do autor, se desenvolve em seus romances; é precisamente a multiplicidade de consciências equipolentes e seus mundos que aqui se combinam numa unidade de acontecimento, mantendo a sua imiscibilidade (BAKHTIN, 1981, p.2, grifos nossos).

As artes de Eugênio Sigaud e Chico Buarque propõem, portanto, a mudança de um sistema - o sistema ditatorial da Era Vargas e o sistema ditatorial militar - por meio da criação de sujeitos que "refletem e refratam" a "realidade" social brasileira com o propósito de invertê-la. Dessa maneira, ao abordarmos os conceitos de "sujeito", "poder", "história" e "discurso", sob a ótica da análise do discurso, pudemos entender a organização de um aspecto principal do discurso dos autores: o aspecto crítico. Todavia, longe de querermos esgotar os vários sentidos e as várias leituras que podem ser apreendidos dessas obras, propusemos uma das leituras possíveis sob o olhar bakhtiniano, pois como afirma o próprio autor:

Qualquer enunciação, por mais significativa e completa que seja, constitui apenas uma fração de uma corrente de comunicação verbal ininterrupta (concernente à vida cotidiana, à literatura, ao conhecimento, à política, etc.). Mas essa comunicação verbal ininterrupta constitui, por sua vez, apenas um momento na evolução contínua, em todas as direções, de um grupo social determinado (BAKHTIN; VOLOSHINOV,1990, p.123). 


\section{Referências}

ABE, A. T. Grande Vitória, E.S: crescimento e metropolização. São Paulo: Tese de Doutorado em Arquitetura e Urbanismo, FAU-USP, 1999.

ALVAREZ, A. G. R. As relações na paródia de Almeida Faria. In: LOPONDO, L. (Org.). Dialogia na literatura portuguesa. São Paulo: Scortecci, 2006.

BAKHTIN, M. Problemas da poética de Dostoiévski. Trad. Paulo Bezerra. Rio de Janeiro: Forense-Universitária, 1981.

- Questões de literatura e estética. Trad. Aurora Fornoni Bernardini e outros. São Paulo: Hucitec, 1988.

; VOLOCHINOV, V. N. Marxismo e filosofia da linguagem: Problemas fundamentais do método sociológico na ciência da linguagem. Trad. Michel Lahud e Yara Frateschi Vieira. $8^{\circ}$ ed. São Paulo: Hucitec, 1990.

. Estética da criação verbal. Trad. Paulo Bezerra. 4. Ed. São Paulo: Martins Fontes, 2003.

BARROS, D. L. P.; FIORIN, J. L. (Org.). Dialogismo, polifonia, intertextualidade. São Paulo: Edusp, 2003.

BRAGA, R. Disponível em: www.sumo.tv/watch.php. Acessado em: 26 abr. 2009.

FARACO, C. A. Linguagem \& diálogo: as idéias lingüísticas do círculo de Bakhtin. Curitiba: Criar Edições, 2003.

FIORIN, J. L. Introdução ao pensamento de Bakhtin. São Paulo: Ática, 2008.

FOUCAULT, M. Vigiar e punir. Petrópolis: Vozes, 2003. 
HUTCHEON, L. Uma teoria da paródia: ensinamento das formas de arte do século XX. Trad. Teresa Louro Pérez. Lisboa: Edições 70, 1985.

KOGAWA, J. M. M. O discurso-arte de Chico Buarque: poder sobre o sujeito brasileiro. Revista Urutágua - revista acadêmica multidisciplinar. Maringá, n. 07, dez. 2007.

MEDEIROS, C. M. O sujeito bakhtiniano: um ser de resposta. Revista da Faculdade do Seridó. Seridó, v.1, n.0, jan./jun. 2006.

NICOLA, J. Literatura brasileira: das origens aos nossos dias. São Paulo: Scipione, 2003.

ROSA, Nereide S. Santa. Cândido Portinari. São Paulo: Moderna, 1999. Coleção mestres das artes no Brasil.

SENKEVICS, A. Disponível em: www.letrasdespidas.wordpress.com. Acessado em: 06 mai. 2009. 


\section{Anexos}

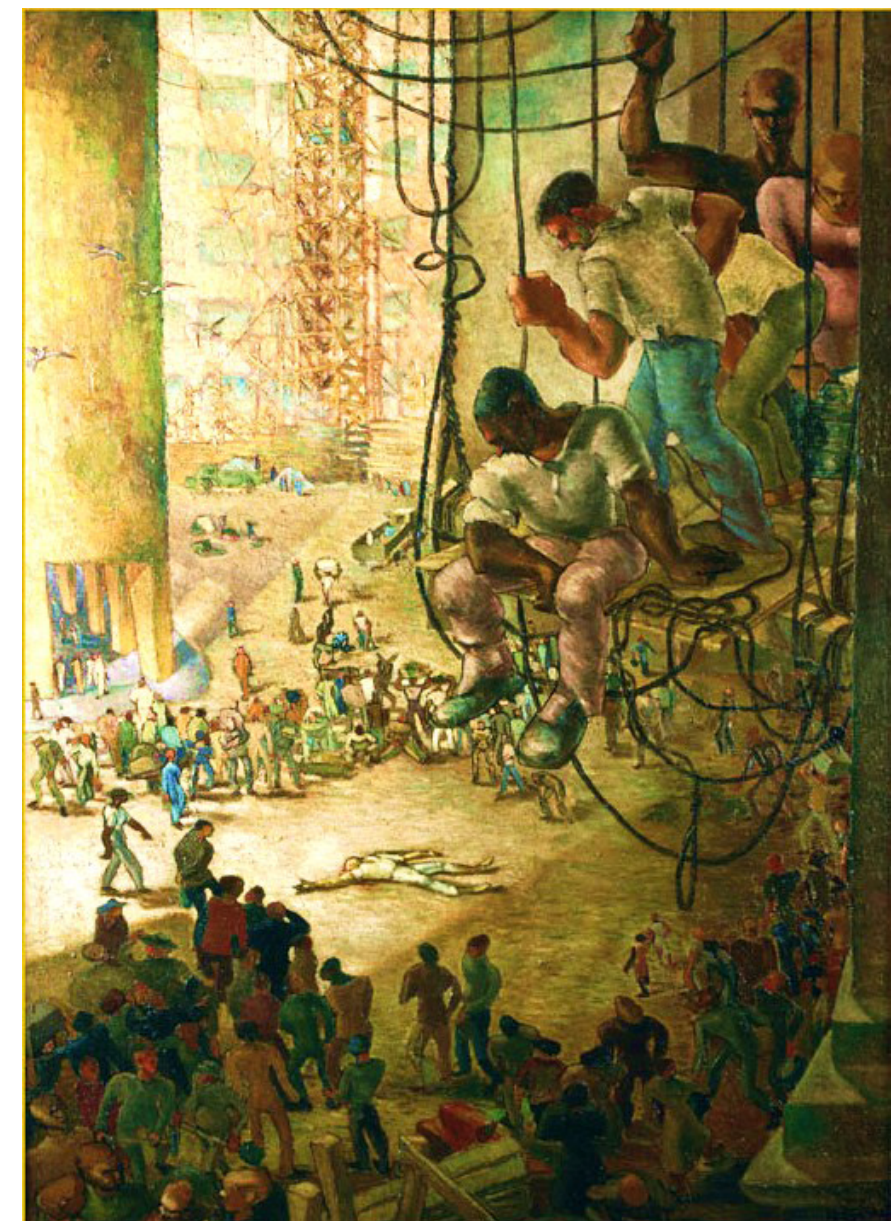

Figura 1: Acidente de trabalho, Eugênio Sigaud, 1944.

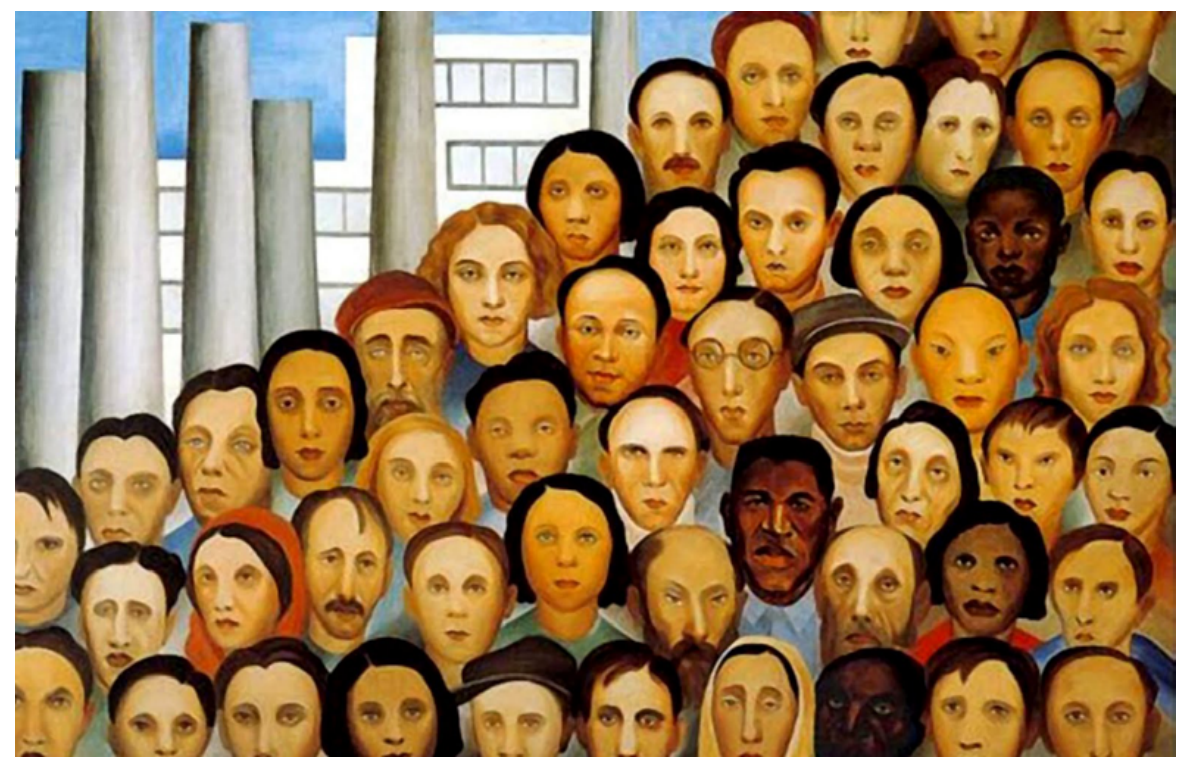

Figura 2: Operários, Tarsila do Amaral, 1933. 


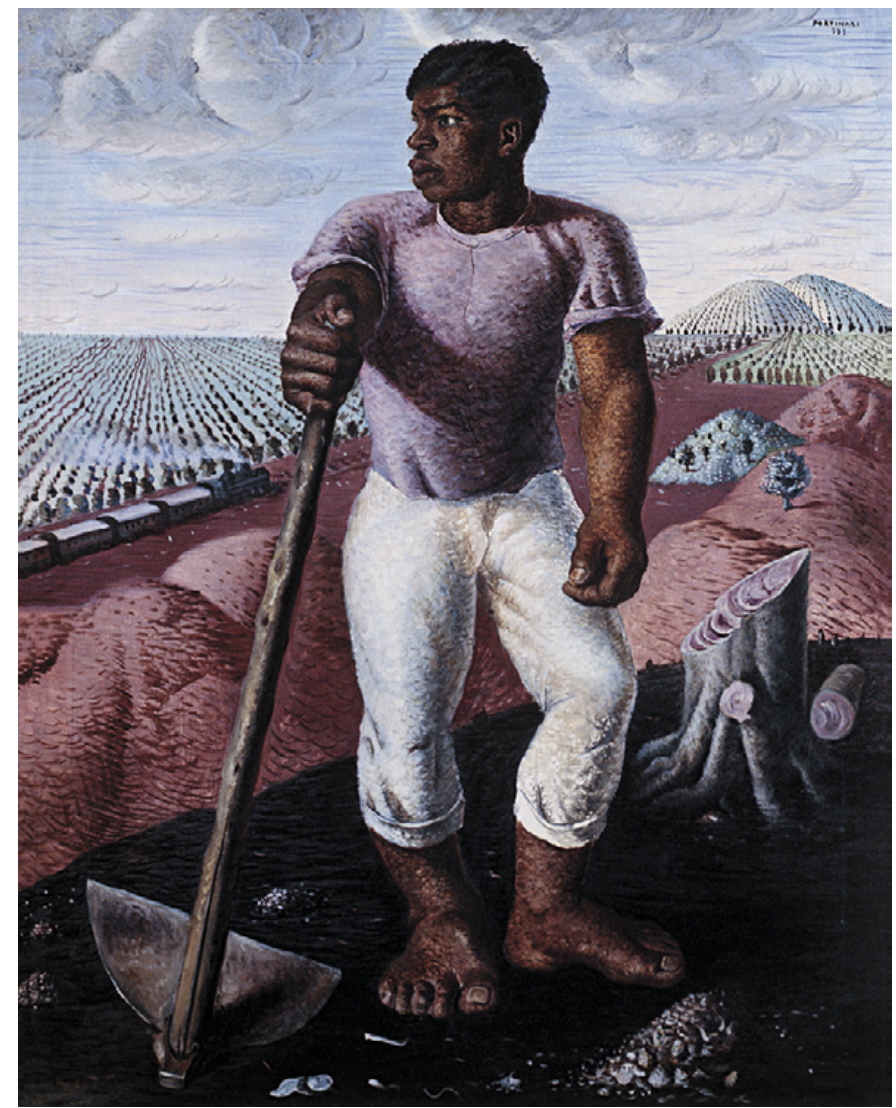

Figura 3: Lavrador de café, Cândido Portinari, 1934.

\section{Construção, Chico Buarque, 1971.}

Amou daquela vez como se fosse a última

Beijou sua mulher como se fosse a última

E cada filho seu como se fosse o único

E atravessou a rua com seu passo tímido

Subiu a construção como se fosse máquina

Ergueu no patamar quatro paredes sólidas

Tijolo com tijolo num desenho mágico 
Seus olhos embotados de cimento e lágrima

Sentou pra descansar como se fosse sábado

Comeu feijão com arroz como se fosse um príncipe

Bebeu e soluçou como se fosse um náufrago

Dançou e gargalhou como se ouvisse música

E tropeçou no céu como se fosse um bêbado

E flutuou no ar como se fosse um pássaro

E se acabou no chão feito um pacote flácido

Agonizou no meio do passeio público

Morreu na contramão atrapalhando o tráfego

Amou daquela vez como se fosse o último

Beijou sua mulher como se fosse a única

E cada filho como se fosse o pródigo

E atravessou a rua com seu passo bêbado

Subiu a construção como se fosse sólido

Ergueu no patamar quatro paredes mágicas

Tijolo com tijolo num desenho lógico

Seus olhos embotados de cimento e tráfego

Sentou pra descansar como se fosse um príncipe

Comeu feijão com arroz como se fosse o máximo

Bebeu e soluçou como se fosse máquina

Dançou e gargalhou como se fosse o próximo

E tropeçou no céu como se ouvisse música

E flutuou no ar como se fosse sábado 
E se acabou no chão feito um pacote tímido

Agonizou no meio do passeio náufrago

Morreu na contramão atrapalhando o público

Amou daquela vez como se fosse máquina

Beijou sua mulher como se fosse lógico

Ergueu no patamar quatro paredes flácidas

Sentou pra descansar como se fosse um pássaro

E flutuou no ar como se fosse um príncipe

E se acabou no chão feito um pacote bêbado

Morreu na contra-mão atrapalhando o sábado 